\title{
Effect of cyclosporine therapy in transplanted patients-diagnostic values of tubular markers
}

\author{
Todor Gruev ${ }^{1}$, Lidija Petrushevska-Tozi², Koco Chakalarovski³ ${ }^{3}$ Ninonslav Ivanovski ${ }^{3}$ \\ Institute of Clinical Chemistryl, Vodnjanska 17, 1000 Skopje, Republic of Macedonia \\ Faculty of Pharmacy2, Vodnjanska 17, 1000 Skopje, Republic of Macedonia \\ Clinic of Nephrology33, Medical faculty, Vodnjanska 17, 1000 Skopje, Republic of Macedonia
}

Received March 2003; accepted September 2003

\begin{abstract}
The introduction of cyclosporine A (CsA) into the clinical practice has resulted in a major improvement in the short-term outcomes of solid organ transplantation and treatment of autoimune diseases. Chronic ScA nephrotoxicity has been described in kidneys of recepients of renal and other organ allografts. However, the exact mechanism underlying the development of fibrosis in chronic CsA nephrotoxicity has remained poorly understood. Evaluation with the validation data set showed that noninvasive urine protein differentiation might be a useful diagnostic strategy in nephrology. Over the past decade numerous studies in patients after transplantation have demonstrated that renal tubular cell injury after a toxic insult, results in sloughing of tubular debris and cell into the tubular lumen with eventual obstruction of tubular flow, increased intratubular pressure and backleak of glomerular filtrate out of the tubule. Urinary enzymes and low molecular proteins have been recommended as useful markers for the detection of changes in the kidney tissue in cases after renal transplantation.

The aim of our study was to monitor the concentration and eventual nephrotoxic effect of Cyclosporine $A$ using the concentration of low molecular proteins $\alpha$-1-microglobulin and $\beta-2$-microglobulin, serum Cystatin C, as well as the concentration of isoform of GST- $\alpha$ and $\pi$.
\end{abstract}

Key words: Cyclosporine A, $\alpha-1$-microglobulin, $\beta-2$-microglobulin, Cystatin C, $\alpha / \pi$ GST

\section{Introduction}

The renal tubular system consists of several segments with special functions. It is known that various pathological processes and toxins influence on specific parts of the system, initially very fast, leaving the others undamaged (1). Therefore, diagnosis of processes affecting specific segments of the tubular system requires complementary methods specific for different portions of the nephron. Urinary enzymes and specific proteins in urine have been recommended as useful markers for the detection of changes in the kidney tissue in cases with acute renal failure, acute tubular necrosis, acute rejection episode and nephrotoxicity in cases after transplantation $(1,2)$.

The most common and potential limiting consequence of Cyclosporine therapy is renal dysfunction (3). Coupled with renal pathological changes and systemic hypertension, this adverse effect can lead to chronic and even endstage kidney failure (4).

E mail: todorgruev@hotmail.com Prof. Dr.T.Gruev Tel. 3119 080,
Cyclosporine is a neutral, cyclic polipeptide with 11 amino acids, which is extremely hydrophobic. This is related partialy to its wide volume of distribution and high concentration in fat, liver and pancreas. The kidney does not preferentially accumulate extentsive tissue stores of cyclopsporine. Cyclosporines is highly bound to red cells and lipoproteins in blood, and in fact, only $5-10 \%$ of the drug remains "free". Therefore, variation in lipoprotein and hematocrit values may affect therapeutic efficacy and toxicity. Due to limited excretion of unchanged cyclosporine or its metabolites by the kidney, no dosage adjusments are required for patients with pre-existing renal dysfunction (3).

Throughout the extensive metabolism, cyclosporine is metabolized to multiple metabolites by hepatic cytochrome P-450, mixed-function-oxidase enzymes. This leads to clinical relevant drug interactions. Drugs that inhibit cytochrome P-450 enzymes increase concentration of parent cyclosporine and may cause nephrotoxicity, hypertension and other side-effects. Conversely, drugs that induce these enzymes reduce parent cyclosporine concentration and lead to reductions in the drugs immunosuppressive to the unchanged drug. 
Cyclosporine (CsA) has improved one-year allograft survial in renal, liver, heart and pancreas transplantation, and has lately also been advocated as a promising treatment for some autoimmune diseases (3). However, the use of CsA is associated with major nephrotoxicity, very likely being a consequence of its toxic effect on vascular endothelium, consistently documented in experimental animals and humans. Evidence is now available that in kidney transplant recipients, each oral dose of CsA if followed by a transient reduction in renal plasma flow and glomerular filtration rate that results from a form of acute reversible renal hypoperfusion (5).

The aim of our study was:

- To select the urinary enzymes and low molecular urinary proteins which have diagnostic and predictive value for rejection after renal transplantation

- To point out the diagnostic and clinical importance of follow-up study of glomerular and tubular proteins after transplantation

The present investigation is focused especially on pointing out the differences between acute rejection episode (ARE) and CsA nephrotoxicity, using specific urinary enzymes and proteins as markers. It also aims at creating diagnostic laboratory background for the clinicians, and to providing helpful information for identifying the differences between the relevant different complications prior to clinical symptoms, without expansive and dangerous invasive investigation.

\section{Exprimental}

The control group comprised 30 healthy individuals, with no cardiac, liver or renal diseases or hypertension and with normal urine analysis and normal serum urea, creatinine and Cystatin $\mathrm{C}$ concentration.

Urine samples were collected and evaluated from 48 patients after renal transplantation during a period of $24 \mathrm{~h}$ at room temperature, and their volume was measured sometimes second morning urine was also used.

Patients with transplants were classified in two groups due to their clinical diagnosis:

Patients with normal graft function (NGF), $\mathrm{N}=28$, with spontaneous decrease in serum creatinine or Cystatin $\mathrm{C}$ level immediately after transplantation

Patients with acute rejection episode (ARE), $\mathrm{N}=20$, characterized with increasing serum creatinine, Cystatin $\mathrm{C}$ concentration, diminished daily urine volume, graft tenderness and enlargement, and nephrotoxic effects of immunosuppressive therapy (Cyclosporine A)

The concentration of $\alpha$-1-microglobulin, $\beta$-2-microglobulin, IgG, albumin in urune, Cystatin $C$ and $\beta$-2-microglobulin in serum were determined using immunoturbidi- metric method according to DAKO-Instruction cataloque $(\mathrm{mg} / \mathrm{l})(6)$. Urinary enzyme activities of $\mathrm{N}$-acetyl- $\beta$-d-glucosaminidase ( $\beta$-NAG) (7), alanin aminopeptidase (AAP), (U/mmol creatinine) $\alpha / \pi \mathrm{GST}(\mathrm{ng} / \mathrm{l})$ were determined with standard validated methods (8).

\section{Results and disscusion}

The activity of urinary enzymes ( $\beta$, NAG, AAP, $\alpha /$ pi GST) and concentration of low molecular proteins are presented in Table 1. The results showed that the obtained values (SD) were in close correlation with the already published ones $(4,9,10,11)$.

Table 1. Reference interval of investigated parameters

\begin{tabular}{|c|c|c|c|c|}
\hline & $\mathrm{N}$ & $\mathrm{X}$ & $\mathrm{SD}$ & Min-Max \\
\hline $\begin{array}{l}\alpha-1-\text { Microglobulin } \\
\text { urine,mg/l }\end{array}$ & 50 & 10.0 & 2.0 & $8.0-14.0$ \\
\hline $\begin{array}{l}\text { Albuminuria } \\
\text { Mg/1 }\end{array}$ & 50 & 12.0 & 6.0 & $6.0-20.0$ \\
\hline $\begin{array}{l}\beta-\mathrm{NAG}-\mathrm{U} / \mathrm{mmol} \\
\text { creatinine }\end{array}$ & 50 & 0.72 & 0.5 & $0.2-1.20$ \\
\hline $\begin{array}{l}\beta-2 \text { Microglobulin } \\
\text { serum mg/l }\end{array}$ & 50 & 1.65 & 0.66 & $0.65-2.75$ \\
\hline б -GST ng/1 & 50 & 3.7 & 2.3 & $1.4-6.0$ \\
\hline$\pi$-GST ng/1 & 50 & 13.4 & 5.3 & $8.1-18.7$ \\
\hline
\end{tabular}

The excretion of urinary enzymes $\beta$-NAG and AAP has controversial diagnostic value 2-7 postoperative days, although these enzymes can indicate the ability of the graft to regenerate. In significant enzymuria in the early postoperative period, the values decrease to the normal range for 3-5 days. It is important to note that mean values of the investigated enzymes were lower that those of the control group (Fig.1), and they reached the reference values after 6-7 days (AAP $1.38+0.18, \beta$-NAG $0.68+0.35 \mathrm{U} / \mathrm{mmol}$ creatinine).

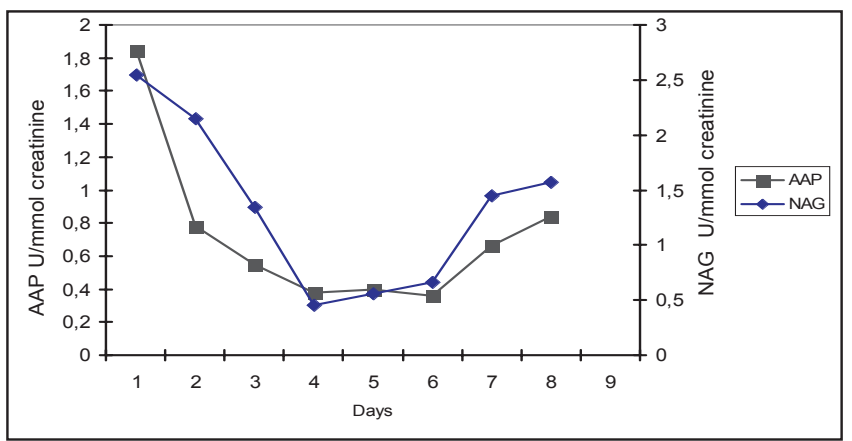

Fig.1. Activity of AAP and $\beta-N A G$ in patients with stable graft function

At the same time, monitoring the concentration of Cystatin $\mathrm{C}$ in serum, the new biomarker of glomerular filtration rate, our results have shown that it decreased more rapidly than creatinine (Fig.2). 


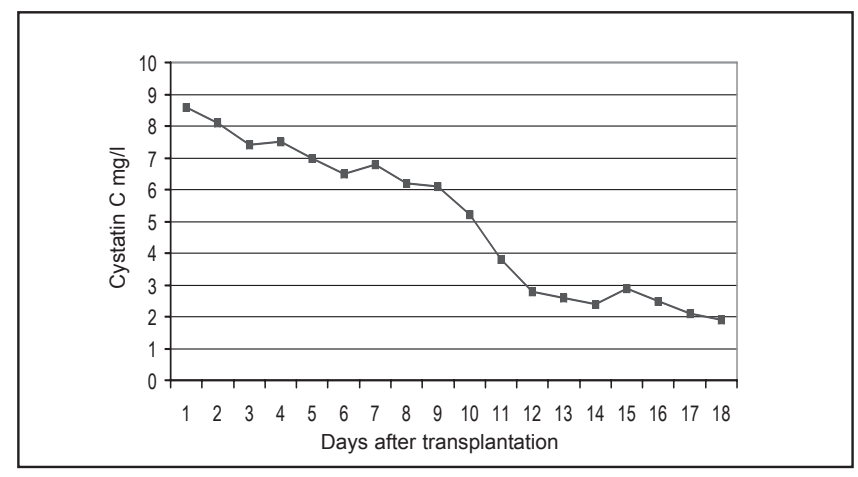

Fig. 2. Concentration of Cystatin $\mathrm{C}$ in serum in patients with stable graft function

The ability (capacity) to detect a reduction in GFR was also shown to be better for serum Cystatin $\mathrm{C}$, than for serum creatinine. Similar results were obtained by Bricon group (12).

In cases of acute rejection episode induced by Cyclosporine A, toxicity changes of Cystatin $\mathrm{C}$ concentration is higher compared with creatinine concentration (Fig.3).

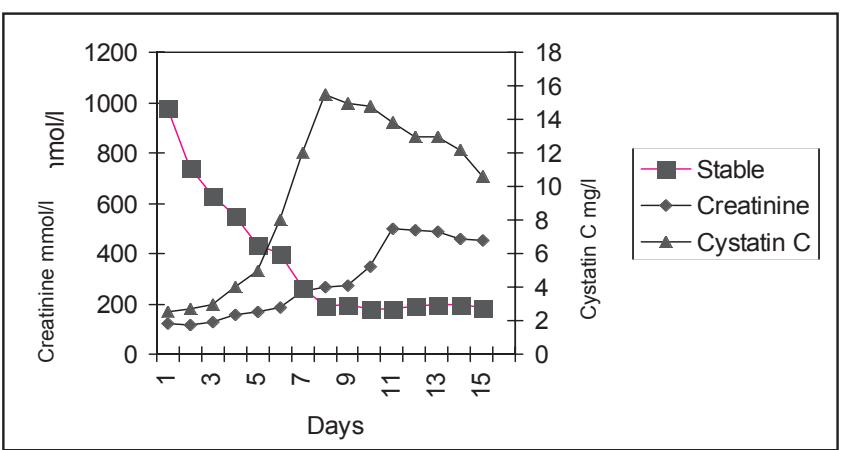

Fig.3. Concentration of creatinine and Cystatin $\mathrm{C}$ in transplanted patients with normal graft function and acute rejection episode induced by high doses of Cyclosporine A.

The changes of $\alpha-1$ microglobulin concentration have confirmed that this low molecular protein is a very sensitive marker of Cyclosporine A toxicity (Fig.4).

Results of the correlation between ARE and CysA toxicity showed high significante elevation in the first two days after transplantation. These results revealed early proximal

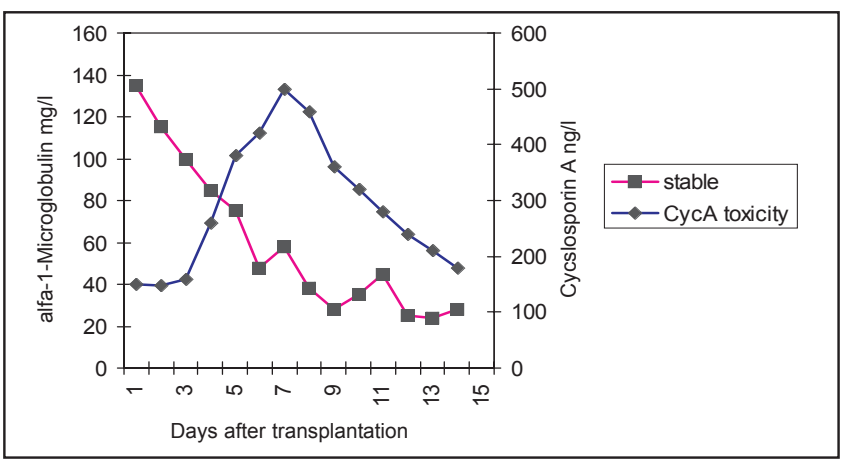

Fig.4. Concentration of $\alpha-1$ microglobulin in urine of patients with stable graft function and patients with acute rejection episode (CsA toxicity) tubular dysfunction. Similar results were shown by Hoffman et al. (13) with application of Urinary Protein expert system (UPES) in the differential diagnosis of kidney diseases.

In case of tubular dysfunction, the measurement of plasma protein $\beta-2$ microglobulin have to provide the most sensitive induction of tubular damage (Fig.5).

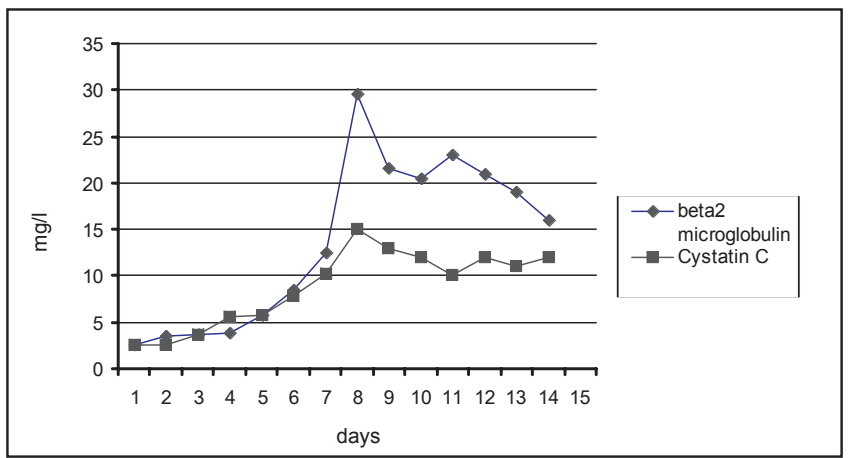

Fig. 5. Concentration of $\beta-2$ - microglobulin in serum of pateints with stable graft function and patients with acute rejection episode

Gluthatione $S$ transferases ( $\alpha /$ pi isoforms) are presented in many different tissues and play a central role in the biotransformation of drugs and toxic chemicals. High concentration of these isoforms can indicate toxic damages (cyclosporine, aminoglycosides), tubular necrosis and rejection of the transplant.

In case of acute rejection, in the early stages of CsAinduced nephrotoxicity, a significant amount of GST- $\alpha$ is excreted into the urine (Fig.6).

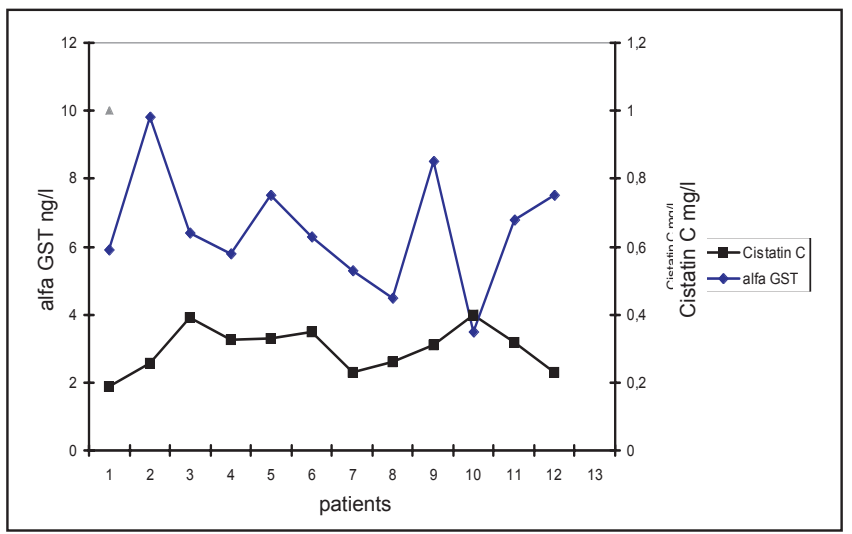

Fig. 6. Concentration of $\alpha$-GST and Cystatin $\mathrm{C}$ in cases with CsA toxicity

In this case no significant elevation of urinary GST- $\pi$ was noticed.These infindings are in agreement with the understanding that in the initial phase of such toxicity, only the proximal tubules are damaged, the distal portion being affected only at a later stage. There two explanations for the appearance of GST-transferases in the urine: excretion from plasma by glomerular filtation or release from damaged cells in the proximal tubular epithelium (14). CsA induced nephrotoxicity in human renal transplant was accompanied 
by high recipients release of $\alpha-$ GST $(\mathrm{p}<0.001)$ and low significant values of $\pi-G S T(p<0.05)$ in urine indicating toxic effect of the drug in the proximal tubular system.

It appears that the assay of different proteins and enzymes in urine and their determination can be used as powerful tool in renal diagnosis in the future, since direct methods like needle biopsy, are relatively complicated and very invasive. Further studies in order to determine to what extent these tests are useful in identifying differences between glomerular and tubular diseases are also needed.

\section{References}

1. L.A.H. Campbell, A.V. Corrigal, A. Guy, R.E. Kirsch, Cancer, 67,1608-1613 (1991).

2. R. Corbert, G.J. Gardner, P.R.N. King, A.E. Thompson, R. Price, Clin.Chim.Acta, 128,141-150 (1983).

3. W.M. Bennet, E.A. Burdmann,T.F. Andoh, D.C. Houghton, J. Lindsley and L.W. Elzinga, Nephrol. Dial. Transpl., 9, Suplpl. 4, 141-145 (1994).
4. E. Coli, A. Botey and L. Alvares, Am. J. Kidney Dis., 36, 29-34 (2000).

5. L. Backman, E.L. Appelkvist, O. Ringden and G. Dallner, Kidney Inter., 33, 571-577 (1988).

6. Dako Cytomation: Clinical Immunochemistry, 239-246 (2003).

7. G. Klein and E. Geibel, Prodr. Med. Lab., 4/4, 450 (1990).

8. W.P. Raab, Clin. Chem., 18,5-25 (1972).

9. E. Sarvary, P. Borka, B. Sulyok, A. Peter and Z. Vass, Transpl. Inty., 9 (Suppl), S68-S72, (1996).

10. S. Tian, E. Kisano, J. Ohara, K. Tabri, Y. Iton and T. Kava, Clin. Nephr., 48, 104-108 (1997).

11. R.D. Perrowe and N.E. Madias, Clin. Chem., 88, 1933-53 (1992).

12. T. Bricon, E. Thervel and M. Froisaat, Clin. Chem., 46, 1206-1207 (2000).

13. W. Hoffman and W. Guder, Clin. Nephrology, 38 Suppl.1, S3-S7 (1992).

14. A.Sundberg, E.L. Appelkvist and L. Backman, Nephron, 67, 308-316 (1994).

\title{
Резиме
}

\section{Ефект на циклоспоринската терапија кај трансплантирани пациенти - дијагностичко значење на тубуларните маркери}

\author{
Тодор Груев ${ }^{*}$, Лидија Петрушевска-Този 2 Кочо Чакаларовски ${ }^{3}$, \\ Нинослав Ивановски ${ }^{3}$,

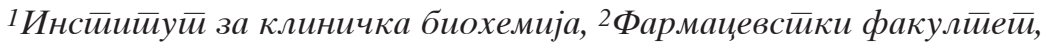 \\ ${ }^{3}$ Клиника за Нефролог̄ија, Скойје, Македонија
}

Клучни зборови: циклоспорин А, нефротоксичност, $\alpha-1$ микроглобулин, $\beta-2$ микроглобулин, Cistatin C, $\alpha \AA$ GST, NAG

Примената на циклоспорин А во клиничката практика кај пациенти со извршена бубрежна трансплантација резултира со нарушувања во функцијата на бубрезите, доведувајќи до компликации, како акутна нефротоксичност, хронична тубулоинтестицијална фиброза и појава на хемолитички уремичен синдром. Со употребата на релевантни т.н. тубуларни и гломелуларни маркери постигнат е напредок во следењето на состојбата на бубрежната функција во првите денови по трансплантацијата. Следењето на концентрацијата на циклоспорин А во серум, како и тубуларните маркери во урина како : $\alpha-1$ микроглобулин, $\beta-2$ микроглобулин, $\alpha /$ рі Глутатион С трансфераса, NAG, AAP како и Cystatin C (нов биомаркер за гломеруларната филтрациона брзина) во голема мера ја дополнуваат клиничката слика кај овие пациенти.

Целта на оваа студија е да се укаже на осетливоста и на раните промени на биохемиските маркери за навремено укажување на локализацијата и степенот на бубрежното оштетување под влијание на нефротоксични агенси. Врз основа на добиените резултати, обработени со помош на UPES (urinary protein expert system), се добива комплетна биохемиско-клиничка слика за моменталната состојба на трансплантантот (стабилна фаза, фаза на почетна реакција, акутна реакција на отфрлување, односно нефротокичност предизвикана од имуносупресивната терапија). 